\title{
KEDUDUKAN KETETAPAN MAJELIS PERMUSYAWARATAN RAKYAT DALAM UNDANG-UNDANG NOMOR 12 TAHUN 2011 TENTANG PEMBENTUKAN PERATURAN PERUNDANG-UNDANGAN
}

\author{
Oleh : H. ENDANG SUPRIATNA, S.H., M.Si. dan EVI NOVIAWATI, S.H., M.H.”)
}

\begin{abstract}
People's Consultative Assembly Decree or the abbreviated TAP MPR is one source of law in Indonesia. Decrees of the People's Consultative Assembly can not be separated from the position and authority of the People's Consultative Assembly of Indonesia in the state system.

Amendment of the Constitution of the Republic of Indonesia Year 1945 after the reform consequence of the position and the authority attached to the People's Consultative Assembly.
\end{abstract}

\section{ABSTRAK}

Ketetapan Majelis Permusyawaratan Rakyat atau yang disingkat TAP MPR merupakan salah satu sumber hukumyang berlaku di Indonesia.Kedudukan Ketetapan Majelis Permusyawaratan Rakyat tidak bisa dipisahkan dengan kedudukan dan kewenangan Majelis Permusyawaratan Rakyat dalam sistem ketatanegaraan Indonesia.

Perubahan Undang-Undang Dasar Republik Indonesia Tahun 1945 pasca reformasi membawa konsekuensi terhadap kedudukan serta kewenangan yang melekat kepada Majelis Permusyawaratan Rakyat.

\footnotetext{
${ }^{*}$ Dosen Fakultas Hukum Universitas Galuh
} 


\section{Pendahuluan}

Indonesia sebagai negara hukum mempunyai kewajiban untuk melaksanakan pembangunan hukum nasional yang dilakukan secara terencana, terpadu, dan berkelanjutan dalam sistem hukum nasional yang menjamin perlindungan hak dan kewajiban segenap rakyat Indonesia berdasarkan UndangUndang Dasar Negara Republik Indonesia Tahun 1945.

Dalam mewujudkan cita-cita bangsa Indonesia sebagai negara hukum dimana segala aspek kehidupan dalam bidang kemasyarakatan, kebangsaan, dan kenegaaraan termasuk pemerintahan harus berdasarkan atas hukum yang sesuai dengan sistem hukum nasional. Sistem hukum nasional merupakan hukum yang berlaku di Indonesia dengan semua elemennya yang saling menunjang satu dengan yang lainnya dalam rangka mengantisipasi dan mengatasi permasalahan yang timbul dalam kehidupan bermasyarakat, berbangsa, dan bernegara yang berdasarkan Pancasila dan Undang-Undang Dasar Negara Republik Indonesia Tahun 1945.

Dalam membentuk peraturan perundang-undangan harus dilakukan berdasarkan pada asas-asa pembentukan peraturan perundang-undangan yang baik, yang meliputi :
a. Kejelasan tujuan;
b. Kelembagaan atau pejabat pembentuk yang tepat;
c. Kesesuaian antara jenis, hierarki dan materi muatan;
d. Dapat dilaksanakan;
e. Kedayagunaan dan kehasilgunaan;
f. Kejelasan rumusan; dan
g. Keterbukaan.

Berdasarkan Undang-undang Nomor 12 Tahun 2011 tentang Pembentukan Peraturan Perundang-undangan menyatakan bahwa tata urutan atau hierarki peraturan perundang-undangan di Indonesia terdiri dari :

1. Undang-Undang Dasar Republik Indonesia Tahun 1945;

2. Ketetapan Majelis Permusyawaratan Rakyat;

3. Undang-Undang/Peraturan Pemerintah Pengganti Undang-Undang;

4. Peraturan Pemerintah;

5. Peraturan Presiden;

6. Peraturan Daerah Provinsi; 


\section{Peraturan Daerah Kabupaten/Kota;}

Ketetapan Majelis Permusyawaratan Rakyat atau yang disingkat TAP MPRmerupakan salah satu sumber hukumyang berlaku di Indonesia.Bahkan didalam hierarki peraturan perundang-undangan, Ketetapan Majelis Permusyawaratan Rakyat memiliki kedudukan lebih tinggi dibandingkan dengan Undang-Undang/Peraturan Pemerintah Pengganti Undang-Undang, Peraturan Pemerintah, Peraturan Presiden dan Peraturan Daerah.

Meskipun dalam Undang-undang sebelumnya, yakni Undang-undang Nomor 10 Tahun 2004 tentang Pembentukan Peraturan Perundang-undangan, Ketetapan Majelis Permusyaaratan Rakyat tidak dimasukkan dalam hierarki perundang-undangan, bukan berarti keberadaan Ketetapan Majelis Permusyawaratan Rakyat tidak diakui sebagai salah satu sumber hukum, akan tetapi norma yang diatur dalam setiap Ketetapan Majelis Permusyawaratan Rakyat sejak tahun 1966 hingga tahun 2002 tetap diakui sebagai sebuah produk hukum yang berlaku sepanjang tidak digantikan dengan Undang-undang formal yang ditetapkan setelahnya.

Dimasukkannya kembali Ketetapan Majelis Permusyawaratan Rakyat dalam tata urutan perundang-undangan berdasarkan apa yang tertuang dalam Undang-undang Nomor 12 Tahun 2011 tentang Pembentukan Peraturan Perundang-undangan, hanya merupakan bentuk penegasan saja bahwa produk hukum yang dibuat berdasarkan Ketetapan Majelis Permusyawaratan Rakyat masih diakui dan berlaku secara sah dalam sistem perundang-undangan Indonesia. Oleh karena hal-hal tersebut, maka ada beberapa pokok permasalahan yang memerlukan pembahasan lebih lanjut terkait dengan keberadaan Ketetapan Majelis Permusyawaratan Rakyat dalam sistem perundang-undangan di Indonesia, yaitu :

1. Apakah implikasi atau akibat hukum yang timbul dengan diterbitkannya Undang-undang Nomor 12 Tahun 2011 tentang Pembentukan Peraturan Perundang-undangan terhadap Ketetapan Majelis Permusyawaratan Rakyat?

2. Bagaimanakah pengujian materil terhadap Ketetapan Majelis Permusyawaratan Rakyat? 


\section{Pembahasan}

A. Pengertian dan Istilah Perundang-undangan :

Dalam kamus umum yang berlaku istilah Perundang-undangan yang dalam bahasa Inggris adalah legislation dapat diartikan dengan perundangundangan dan pembuatan undang-undang. Istilah wetgeving dalam bahasa Belanda diterjemahkan dengan pengertian membentuk undang-undang, dan keseluruhan daripada undang-undang negara. Istilah Gesetzgebungdalam bahasa Jerman diterjemahkan dengan pengertian perundang-undangan.

Pengertian wetgeving dalam Juridisch woordenboek diartikan sebagai berikut :

a. Perundang-undangan merupakan proses pembentukan atau proses membentuk peraturan negara, baik di tingkat pusat maupun tingkat daerah;

b. Perundang-undangan adalah segala peraturan negara, yang merupakan hasil pembentukan peraturan, baik di tingkat pusat maupun di tingkat daerah.

Menurut Bagir Manan, banyak kalangan yang menganggap hukum, peraturan perundang-undangan dan undang-undang adalah hal yang sama. Padahal hal tersebut tidaklah sama. Undang-undang adalah bagian dari peraturan perundang-undangan. Peraturan perundang-undangan terdiri dari undang-undang dan berbagai peraturan perundang-undangan lain, sedangkan hukum bukan hanya undang-undang, melainkan termasuk juga beberapa kaidah hukum seperti hukum adat, kebiasaan, dan hukum yurisprudensi.

Sedangkan Satjipto Rahardjo, memberikan batasan mengenai perundang-undangan yang menghasilkan peraturan, dengan cirri-ciri sebagai berikut :

1. Bersifat Umum dan Komprehensif;

Bahwa perundang-undangan merupakan kebalikan dari sifat-sifat yang khusus dan terbatas.

2. Bersifat Universal;

Perundang-undangan diciptakan untuk menghadapi peristiwa-peristiwa yang akan datang yang belum jelas bentuk kongkritnya. Oleh karena itu perundang-undangan tidak dapat dirumuskan untuk mengatasi peristiwaperistiwa tertentu saja. 
3. Perundang-undangan memiliki kekuatan untuk mengoreksi dan memperbaiki dirinya sendiri;

Sehingga lazim bagi suatu peraturan untuk mencantumkan klausul yang memuat kemungkinan dilakukannya peninjauan kembali.

Pendapat Satjipto Rahardjo tersebut melahirkan konsekuensi, bahwa pengertian dan definisi peraturan perundang-undangan dikunci pada aspek ketentuan yang mengatur (regeling) dengan sifat berlaku umum, tidak kongkrit dan ditujukan untuk publik. Hal tersebut berbeda dengan sifat yang melekat dalam suatu keputusan (becshikking) yang bersifat kongret, individual dan berlaku sekali waktu (einmalig). Jika ditarik dalam konteks sistem perundang-undangan Indonesia, maka suatu produk hukum dalam setiap tingkatan kelembagaan Negara dapat dikatakan sebagai bagian dari peraturan perundang-undangan, jika memenuhi unsur peraturan (regeling) sebagaimana yang disebutkan oleh Satjipto Rahardjo tersebut.

Setidaknya ada 2 (dua) aspek yang mendasari struktur dan karakterisitik peraturan perundang-undangan dimasing-masing Negara.

1. Ilmu pengetahuan yang berkembang di Negara yang bersangkutan;

2. Sistem ketatanegaraan yang berlaku di Negara tersebut.

Di Indonesia peraturan perundang-undangan sangat ditentukan oleh sistem ketatanegaraan yang berlaku. Hal ini juga tidak terlepas dari adopsi dari sistem ketatanegaraan penganut sistem hukum Eropa Continental.

Hal ini sejalan dengan pendapat A. Hamid S. Attamimi, yang menegaskan bahwa teori perundang-undangan yang berkembang di Eropa Continental hendak memodernisasikan pranata ketatanegaraan pada umumnya dan pranata perundang-undangan pada khususnya, sehingga perlu juga dilihat, dibandingkan, dan jika perlu ditiru sistemnya di negara lain. Akan tetapi cita dan filsafat yang mendasarinya, nilai-nilai titik tolaknya, pengertian dan pemahaman dasarnya, serta ruang lingkup dan tata kerja penyelenggaraannya, singkatnya paradigma-paradigmanya, harus tetap mempertahankan apa yang digariskan oleh Cita Negara Kekeluargaan Rakyat Indonesia, Teori Bernegara Bangsa Indonesia, dan Sistem Penyelenggaraan Pemerintahan Negara Republik Indonesia, sebagaimana termaktub dalam Hukum Dasar kita, yaitu Undang-Undang Dasar 1945. 
B. Kedudukan dan Kewenangan Majelis Permusyawaratan Rakyat

Kedudukan Ketetapan Majelis Permusyawaratan Rakyat tidak bisa dipisahkan dengan kedudukan dan kewenangan Majelis Permusyawaratan Rakyat dalam sistem ketatanegaraan Indonesia. Perubahan Undang-Undang Dasar Republik Indonesia Tahun 1945 pasca reformasi membawa konsekuensi terhadap kedudukan serta kewenangan yang melekat kepada Majelis Permusyawaratan Rakyat. Salah satu perubahan penting dalam Undang-Undang Dasar Republik Indonesia Tahun 1945 yang mempengaruhi kedudukan dan kewenangan Majelis Permusyawaratan Rakyat adalah perubahan pada bagian bentuk dan kedaulatan Negara khususnya pada Pasal 1 ayat (2) Undang-Undang Dasar Republik Indonesia Tahun 1945.

Sebelum perubahan Undang-Undang Dasar Republik Indonesia Tahun 1945 disebutkan bahwa, "Kedaulatan adalah ditangan rakyat, dan dilakukan sepenuhnya oleh Majelis Permusyawaratan Rakyat". Sedangkan setelah perubahan diubah menjadi, "Kedaulatan berada di tangan rakyat dan dilaksanakan menurut Undang-Undang Dasar".

Perubahan yang signifikan juga terlihat pada Pasal 3 Undang-Undang Dasar Republik Indonesia Tahun 1945. Jika sebelum perubahan Majelis Permusyawaratan Rakyat diberikan kewenangan untuk menetapkan GarisGaris Besar daripada Haluan Negara (GBHN), maka setelah perubahan kewenangan tersebut sudah tidak diberikan lagi kepada Majelis Permusyawaratan Rakyat.

Pada masa lalu, konsekuensi dari kedudukan dan kewenangan Majelis Permusyawaratan Rakyat untuk menetapkan Garis-Garis Besar daripada Haluan Negara (GBHN), mengakibatkan eksistensi Ketetapan Majelis Permusyawaratan Rakyat Sementara (MPRS) sebagai salah satu pengaturan perundang-undangan yang memuat pengaturan. Hal ini kemudian semakin dipertegas dengan adanya Ketetapan MPRS Nomor XX/MPRS/1966 yang menempatkan Ketetapan Majelis Permusyawaratan Rakyat sebagai salah satu peraturan perundang-undangan yang memiliki derajat di bawah UndangUndang Dasar.

Menurut Mahfud MD, bahwa Pemosisian Ketetapan Majelis Permusyawaratan Rakyat sebagai peraturan perundang-undangan dalam derajat kedua (di bawah Undang-Undang Dasar Republik Indonesia Tahun 
1945) sebenarnya hanyalah tafsiran MPRS saja, sebab Undang-Undang Dasar sendiri tidak menyebutkan bahwa TAP MPR itu harus berisi pengaturan (regeling) dan berbentuk peraturan perundang-undangaan, Menetapkan itu sebenarnya dapat hanya diartikan sebagai penetapan (beschikking) yang bersifat konkret, individual.

Secara umum, implikasi dari perubahan Undang-Undang Dasar Republik Indonesia Tahun 1945, tentu saja memberikan akibat perubahan kedudukan dan kewenangan Majelis Permusyawaratan Rakyat pula. Setidaknya terdapat 3 (tiga) implikasi mendasar akibat perubahan UndangUndang Dasar Republik Indonesia Tahun 1945 terhadap kedudukan dan kewenangan Majelis Permusyawaratan Rakyat, antara lain :

1. Majelis Permusyawaratan Rakyat (MPR) tidak lagi menjadi lembaga tertinggi Negara sebagai perwujudan Pasal 1 ayat 2 Undang-Undang Dasar Republik Indonesia Tahun 1945, yakni menjadi representasi absolut dari kedaulatan rakyat Indonesia. MPR setelah perubahan UndangUndang Dasar Republik Indonesia Tahun 1945, kini memiliki kedudukan sederajat dengan lembaga tinggi Negara lainnya, yakni Lembaga Kepresidenan, Dewan Perwakilan Rakyat (DPR), Dewan Perwakilan Daerah (DPD), Badan Pemeriksa Keuangan (BPK), Mahkamah Agung dan Mahkamah Konstitusi.

2. Sebagai konsekuensi MPR yang tidak lagi menjadi lembaga tertinggi Negara, maka MPR bukanlah lembaga perwakilan, akan tetapi cendrung menjadi "joint sesion" antara anggota DPR dan anggota DPD yang memiliki fungsi bersifat lembaga konstituante yang bertugas merubah dan menetapkan Undang-undang Dasar. Secara implisit, roh atau eksistensi MPR menjadi ada atau diadakan jika berkenaan dengan kewenangan yang diberikan oleh UUD Negara Republik Indonesia Tahun 1945. Sebagaimana pendapat Jimly Asshidiqie yang menyatakan bahwa, organ MPR itu sendiri baru dikatakan ada (actual existence) pada saat kewenangan atau fungsinya sedang dilaksanakan.

Dalam pola Negara kesatuan sebagaimana dianut oleh Indonesia, supremasi parlemen yang memegang fungsi legislasi, hanya ada ditangan DPR dan DPD bukan ditangan MPR lagi. 
3. MPR tidak lagi memiliki kewenangan untuk membuat ketetapan yang bersifat mengatur (regeling). MPR setelah perubahan Undang-Undang Dasar Republik Indonesia Tahun 1945hanya diberikan kewenangan dalam membuat ketetapan yang bersifat keputusan (beshickking). Dihilangkannya kewenangan MPR untuk menetapkan Garis-garis Besar Haluan Negara, berarti aturan dasar Negara kita berlaku secara singular atau tunggal yang bertumpu kepada Undang-Undang Dasar Negara Republik Indonesia Tahun 1945. MPR kini tidak lagi berwena Undang-Undang Dasar Republik Indonesia Tahun 1945ng menerbitkan aturan dasar Negara (grundnorm) di luar Undang-Undang Dasar Republik Indonesia Tahun 1945yang bersifat mengatur.

Untuk melihat kedudukan Ketetapan Majelis Permusyawaratan Rakyat dalam sistem perundang-undangan Indonesia, baiknya kita memulai dari teori piramida hukum (stufentheorie) yang diperkenalkan oleh Hans Kelsen. Teori inimengelompokan beragam norma hukum dasar yang berlaku. Teori Hans Kelsen ini kemudian dikembangkan oleh Hans Nawiasky melalui teori yang disebut dengan "theorie von stufenufbau der rechtsordnung". Teori ini memberikan penjelasan susunan norma sebagai berikut :

1. Norma fundamental negara (Staatsfundamentalnorm);

2. Aturan dasar negara (staatsgrundgesetz);

3. Undang-undang formal (formell gesetz); dan

4. Peraturan pelaksanaan dan peraturan otonom (verordnung en autonome satzung).

Berdasarkan teori Hans Nawiasky tersebut, A. Hamid S. Attamimi mengaplikasikannya dalam struktur hierarki perundang-undangan yang berlaku di Indonesia. Berdasarkan teori Nawiasky tersebut, maka tata urutan perundang-undangan di Indonesi adalah sebagai berikut :

1. Staatsfundamentalnorm : Pancasila (Pembukaan Undang-Undang Dasar Republik Indonesia Tahun 1945);

2. Staatsgrundgesetz : Batang Tubuh Undang-Undang Dasar Republik Indonesia Tahun 1945, Tap MPR, dan Konvensi Ketatanegaraan;

3. Formell gesetz : Undang-Undang;

4. Verordnung en Autonome Satzung : Secara hierarkis mulai dari Peraturan Pemerintah hingga Keputusan Bupati atau Walikota. 
Secara garis besar Ketetapan Majelis Permusyawaratan Rakyat dikategorikan sebagai aturan dasar Negara (staatsgrundgesetz) atau dapat juga disebut sebagai norma dasar (grundnorm). Akan tetapi kategorisasi yang dilakukan oleh Attamimi ini dilakukan disaat kedudukan MPR masih sebagai lembaga tertinggi Negara atau sebelum perubahan Undang-Undang Dasar Republik Indonesia Tahun 1945. Kedudukan Ketetapan Majelis Permusyawaratan Rakyat sebelum perubahan Undang-Undang Dasar, memang menjadi salah satu produk hukum yang berada setingkat dengan Undang-Undang Dasar. Hal tersebut mengacu kepada kewenangan dan kedudukan MPR sebagai lembaga perwujudan kedaulatan rakyat dalam sistem ketatanegaraan Indonesia. Hal ini sejalan dengan penjelasan Pasal 3 UndangUndang Dasar Republik Indonesia Tahun 1945, yang menyatakan bahwa, "Oleh karena Majelis Permusyawaratan Rakyat memegang kedaulatan negara, maka kekuasaannya tidak terbatas, mengingat dinamik masyarakat, sekali dalam 5 tahun Majelis memperhatikan segala yang terjadi dan segala aliranaliran pada waktu itu dan menentukan haluan-haluan apa yang hendaknya dipakai untuk di kemudian hari".

Dalam periode era reformasi, Ketetapan Majelis Permusyawaratan Rakyat dianggap sebagai perpanjangan tangan dari kekuasaan untuk membuat peraturan-peraturan tertentu yang menguntungkan atau meligitimasi kepentingan kekuasaan. Untuk itu sedikit demi sedikit terjadi penghapusanKetetapan Majelis Permusyawaratan Rakyat sebagai sumber hukum dalam sistem perundang-undangan Indonesia. Hal ini juga yang mendasari evaluasi yang disertai penghapusan secara besar-besaran terhadap Ketetapan Majelis Permusyawartan Rakyat/Sementara (TAP MPR/S) pada tahun 2003 melalui Sidang Umum (SU) MPR untuk diberikan status baru.

Implementasi dari evaluasi penghapusan TAP MPR/S yaitu dengan diterbitkannya Undang-Undang Nomor 10 Tahun 2004 tentang Pembentukan Peraturan Perundang-undangan, yang tidak memasukkan Ketetapan Majelis Permusyawaratan Rakyat sebagai salah satu sumber hukum.

Mahfud MD berpendapat bahwa Ketetapan Majelis Permusyawaratan Rakyat tetap saja boleh ada dan dikeluarkan oleh Majelis Permusyawaratan Rakyat, tetapi terbatas hanya untuk penetapan yang bersifat beschikking (kongret dan individual) seperti Ketetapan tentang pengangkatan Presiden, 
Ketetapan tentang pemberhentian Presiden dan sebagainya. Bahkan Ketetapan Majelis Permusyawaratan Rakyat tetap dijadikan sebagai sumber hukum yang bersifat materiil. Sebagaimana yang ditegaskan oleh Mahfud MD, bahwa sebagai sumber hukum, Ketetapan Majelis Permusyawaratan Rakyat dapat dijadikan sebagai sumber hukum materiil (bahan pembuatan hukum), namun bukan sumber hukum formal (peraturan perundang-undangan). Sebagai sumber hukum materiil, Ketetapan Majelis Permusyawarata Rakyat bisa menjadi bahan hukum seperti halnya nilai-nilai keadilan yang tumbuh dan berkembang di dalam masyarakat, keadaan sosial dan ekonomi masyarakat, warisan sejarah dan budaya bangsa dan lain-lain.

Dengan diterbitkannya Undang-udang Nomor 12 Tahun 2011 tentang Pembentukan Peraturan Perundang-undangan, dimanaKetetapan Majelis Permusyawaratan Rakyat kembali masuk dalam hierarki peraturan perundangundangan membawa konsekuensi-konsekuensi logis dalam penataaan sistem hukum Indonesia, baik norma, kedudukan, maupun ruang pengujian akibat pertentangan antara sesama produk perundang-undangan lainnya. Keberadaan Undang-udang Nomor 12 Tahun 2011 tentang Pembentukan Peraturan Perundang-undangan, mengakibatkan Ketetapan Majelis Permusyawaratan Rakyat secara otomatis menjadi rujukan dalam pembentukan dan penerapan ketentuan peraturan perundang-undangan yang berada di bawahnya. Dalam hal ini UU/Perpu, PP. Perpres, dan Perda.

Kemudian timbul silang pendapat diantara pengamat hukum ketatanegaraan dan perundang-undangan. Sebagian menyebutkan bahwa keberadaaan Ketetapan Majelis Permusyawaratan Rakyat dalam hierarki perundang-undangan sebagaimana tertuang dalam Undang-udang Nomor 12 Tahun 2011 tentang Pembentukan Peraturan Perundang-undangan, telah memberikan ruang kepada Majelis Permusyawaratan Rakyat untuk kembali merumuskan kembali ketentuan yang mengikat publik. Padahal dalam Sidang Umum Majelis Permusyawaratan Rakyat pada tahun 2003, telah diputuskan bahwa Ketetapan Majelis Permusyawaratan Rakyat tidak lagi mengatur keluar (mengikat publik), namun hanya berlaku bagi intern Majelis Permusyawaratan Rakyat. Dalam Sidang Umum MPR di tahun 2003 tersebut ditegaskan bahwa, ketentuan yang mengikat publik, harus diimplementasikan melalui produk Undang-Undang. Terdapat 2 (dua) alasan yang melatar belakanginya : 
Pertama, perubahan UUD RI Tahun 1945 membawa konsekwensi kewenangan Majelis Permusyawaratan Rakyat yang tidak lagi dapat membuat ketentuan yang mengatur, kecuali yang bersifat kedalam organ Majelis Permusyawaratan Rakyat itu sendiri.

Kedua, Majelis Permusyawaratan Rakyat merupakan lembaga yang menjalankan fungsi dan kewenangan yang diberikan oleh Undang-Undang Dasar Republik Indonesia Tahun 1945, dan Majelis Permusyawaratan Rakyat tidak lagi mempunyai kewenangan untuk membentuk Undang-Undang sebagaimana tertuang dalam UUD RI Tahun 1945 setelah amandemen.

Di dalam Pasal IAturan Tambahan Undang-undang Dasar Negara Republik Indonesia Tahun 1945menyatakan bahwa, "Majelis Permusyawaratan Rakyat ditugasi untuk melakukan peninjauan terhadap materi dan status hukum Ketetapan Majelis Permusyawaratan Rakyat Sementara dan Ketetapan Majelis Permusyawaratan Rakyat untuk diambil putusan pada sidang Majelis Permusyawaratan Rakyat tahun 2003".

Ketetapan Majelis Permusyawaratan Rakyat yang dimaksud dalam ketentuan Pasal 7 ayat (1) huruf b Undang-udang Nomor 12 Tahun 2011 tentang Pembentukan Peraturan Perundang-undangan, bisa djabarkan melalui penjelasan pasal tersebut yang mengatakan bahwa, "Yang dimaksud dengan "Ketetapan Majelis Permusyawaratan Rakyat" adalah Ketetapan Majelis Permusyawaratan Rakyat Sementara dan Ketetapan Majelis Permusyawaratan Rakyat yang masih berlaku sebagaimana dimaksud dalam Pasal 2 dan Pasal 4 Ketetapan Majelis Permusyawaratan Rakyat Republik Indonesia Nomor: I/MPR/2003 tentang Peninjauan Terhadap Materi dan Status Hukum Ketetapan Majelis Permusyawaratan Rakyat Sementara dan Ketetapan Majelis Permusyawaratan Rakyat Tahun 1966 sampai dengan Tahun 2002, tanggal 7 Agustus 2003".

Dalam Ketetapan Majelis Permusyawaratan Rakyat Nomor I/MPR/2003, telah diputuskan yang mana saja Ketetapan Majelis Permusyawaratan Rakyat/Majelis Permusyawaratan Rakyat Sementara (TAP MPR/MPRS) dari total 139 ketetapan sejak tahun 1966 hingga 2002, yang masih berlaku dan tidak berlaku lagi.Dalam TAP MPR Nomor I/MPR/2003 TAP MPR yang ada, diberikan status hukum baru yang dikelompokkan ke dalam 6 (enam) pasal, antara lain : 
- Pasal 1 tentang Ketetapan MPR/MPRS yang dicabut dan dinyatakan tidak berlaku (8 Ketetapan);

- Pasal 2 tentang Ketetapan MPRS/MPR yang dinyatakan berlaku dengan ketentuan (3 Ketetapan);

- Pasal 3 tentang Ketetapan MPRS/MPR yang dinyatakan tetap berlaku sampai dengan terbentuknya pemerintahan hasil pemilihan umum tahun 2004 (8 Ketetapan);

- Pasal 4 tentang Ketetapan MPRS/MPR yang dinyatakan tetap berlaku sampai terbentuknya UU (11 Ketetapan);

- Pasal 5 tentang Ketetapan MPRS/MPR yang dinyatakan masih berlaku sampai ditetapkannya peraturan tata tertib yang baru oleh Majelis Permusyawaratan Rakyat Republik Indonesia hasil pemilihan umum tahun 2004 (5 Ketetapan);

- Pasal 6 tentang Ketetapan MPRS/MPR yang tidak perlu dilakukan tindakan hukum lebih lanjut, baik Karena bersifat final (enimalig), telah dicabut, maupun telah selesai dilaksanakan. (104 Ketetapan)

Berdasarkan pengelompokan di atas, maka TAP MPR yang masih dianggap berlaku tertuang dalam Pasal 2 dan Pasal 4, dengan total sebanyak 13 TAP MPR yang masih berlaku. TAP MPR yang masih berlaku tersebut, adalah :

1. Ketetapan MPRS No. XXV/MPRS.1966 tentang Pembubaran Partai Komunis Indonesia, pernyataan sebagai organisasi terlarang di seluruh Wilayah Indonesia bagi Partai Komunis Indonesia dan larangan setiap Kegiatan untuk Menyebarkan atau Mengembangkan Faham atau Ajaran Komunisme/Marxisme-Leninisme.

2. Ketetapan MPR No. XVI/MPR/1998 tentang Politik Ekonomi Dalam Rangka Demokrasi Ekonomi.

3. Ketetapan MPR No V/MPR/1999 tentang Penentuan Pendapat di Timor Timur.

4. Ketetapan MPRS No. XXIX/MPRS/1966 tentang Pengangkatan Pahlawan Ampera. (dalam perkembangan terakhir telah terbentuk UU No. 20 Tahun 2009 tentang Gelar, Tanda Jasa, dan Tanda Kehormatan)

5. Ketetapan MPR No. XI/MPR/1998 tentang Penyelenggara Negara yang Bersih dan Bebas KKN. 
6. Ketetapan MPR No. XV/MPR/1998 tentang Penyelenggaraan Otonomi Daerah, Pengaturan, Pembagian, dan Pemanfaatan Sumber Daya Nasional yang Berkeadilan, serta Perimbangan Keuangan Pusat dan Daerah dalam NKRI.

7. Ketetapan MPR No. V/MPR/2000 tentang Pemantapan Persatuan dan Kesatuan Nasional.

8. Ketetapan MPR No. VI/MPR/2000 tentang Pemisahan Tentara Nasional Indonesia dan Kepolisian Negara Indonesia.

9. Ketetapan MPR No. VII/MPR/2000 tentang Peran TNI dan Peran Polri.

10. Ketetapan MPR No. VI/MPR/2001 tentang Etika Kehidupan Berbangsa.

11. Ketetapan MPR No. VII/MPR/2001 tentang Visi Indonesia Masa Depan.

12. Ketetapan MPR No. VIII/MPR/2001 tentang Rekomendasi Arah Kebijakan Pemberantasan dan Pencegahan KKN.

13. Ketetapan MPR No. IX/MPR/2001 tentang Pembaharuan Agraria dan Pengelolahan Sumber Daya Alam.

Ketiga-13Ketetapan Majelis Permusyawaratan Rakyat inilah yang dimaksud dalam penjelasan Pasal 7 ayat (1) huruf b Undang-udang Nomor 12 Tahun 2011 tentang Pembentukan Peraturan Perundang-undangan, dengan pengelompokan 11 Ketetapan Majelis Permusyawaratan Rakyat yang sudah tidak berlaku akibat telah dibentuknya Undang-Undang (Pasal 4 TAP MPR Nomor I/MPR/2003) dan 3 TAP MPR yang masih berlaku hingga saat ini (Pasal 2 TAP MPR Nomor I/MPR/2003).

Adapun Ketetapan MPR No V/MPR/1999 tentang Penentuan Pendapat di Timor Timur, secara otomatis tidak berlaku lagi akibat norma yang diatur didalamnya sudah terlaksana. Dengan demikian, sisa 2 Ketetapan MPR yang masih berlaku hingga saat ini akibat status hukumnya yang tidak dicabut atau diganti melalui Undang-Undang. Pertanyaan kemudian muncul, apakah diluar 2 Ketetapan MPR tersebut, Ketetapan MPR dapat dinyatakan berlaku kembali dan dijadikan sebagai sumber hukum formill? Secara logika hukum, hal tersebut mustahil mengingat tidak mungkin keberlakukan peraturan perundang-undangan yang lebih tinggi justru dilegitimas atau dibuat berdasarkan peraturan perundang-undangan yang lebih rendah, dalam hal ini Undang-udang Nomor 12 Tahun 2011 tentang Pembentukan Peraturan Perundang-undangan. 
Dalam hal pengajuan Hak Uji Materiil, tidak ada ketentuan khusus yang mengatur tata cara pengujian Ketetapan Majelis Permusyawaratan Rakyat terhadap Undang-Undang Dasar Tahun 1945 atapun Undang-Undang terhadap Ketetapan Majelis Permusyawaratan Rakyat. Mahkamah Konstitusi tidak boleh serta merta melakukan pengujian terhadap Ketetapan Majelis Permusyawaratan Rakyat kecuali Mahkamah Konstitusi melakukan upaya hukum progresif seperti yang dilakukan selama ini.

Akan tetapi, jika merunut kepada Ketetapan Majelis Permusyawaratan Rakyat Nomor I/MPR/2003 khususnya dalam ketentuan Pasal 4, maka Mahkamah Konstitusi sebenarnya dapat melakukan pengujian terhadap Ketetapan Majelis permusyawaratan Rakyat. Hal tersebut mengingat ketentuan Pasal 4 Ketetapan Majelis Permusyawaratan Rakyat Nomor I/MPR/2003, secara tersirat telah menyamakan kedudukan Kedudukan Majelis Permusyawaratan Rakyat dengan produk Undang-Undang yang diharuskan untuk dibuat sebagai pengganti norma yang diatur dalam Ketetapan Majelis Permusyawaratan Rakyat sebelumnya. Kecuali TAP MPR yang disebutkan dalam Pasal 2 TAP MPR Nomor I/MPR/2003, Mahkamah Konstitusi tidak berwenang mengujinya sebab ketentuan Pasal 2 tersebut tidak mensyaratkan perubahan atau pencabutan melalui Undang-undang sebagaimana yang dipersyaratkan dalam Pasal 4.

\section{Kesimpulan}

Kedudukan dan kewenangan Majelis Permusyawaratan Rakyat sebelum dan sesudah perubahan Undang-Undang Dasar Negara Republik Indonesia Tahun 1945 berbeda. Dengan dimasukkannya Ketetapan majelis Permusyawaratan Rakyat dalam hierarki peraturan perundang-undangan sebagaimana disebutkan dalam Pasal 7 ayat (1) huruf b Undang-udang Nomor 12 Tahun 2011 tentang Pembentukan Peraturan Perundang-undangan, memberikan implikasi hukum, yakni diharuskannya Ketetapan Majelis Permusyawaratan Rakyat sebagai rujukan bagi peraturan perundang-undangan yang berada dibawahnya, baik Undang-Undang/Peraturan Pemerintah Pengganti Undang-Undang, Peraturan Pemerintah, Peraturan Presiden ataupun Peraturan Daerah. 
Ketetapan Majelis Permusyawaratan Rakyat yang dimaksud dalam Pasal 7 ayat (1) huruf b Undang-udang Nomor 12 Tahun 2011 tentang Pembentukan Peraturan Perundang-undangan, adalah Ketetapan Majelis Permusyawaratan Rakyat yang merujuk hasil Sidang Umum Majelis Permusyawaratan Rakyat Tahun 2003 yang melahirkan Ketetapan Majelis Permusyawaratan Rakyat Nomor I/MPR/2003, khususnya pada pasal 2 dan pasal 4.

Setelah perubahan Undang-Undang Dasar Republik Indonesia Tahun 1945, Majelis Permusyawaratan Rakyat tidak lagi memiliki kewenangan untuk membuat ketetapan yang bersifat mengatur (regelling), akan tetapi Majelis Permusyawaratan Rakyat hanya diberikan kewenangan dalam membuat ketetapan yang bersifat keputusan (beshickking).

Pengujian terhadap Ketetapan Majelis Permusyawaratan Rakyat terhadap Undang-Undang Dasar Republik Indonesia Tahun 1945 maupun Undang-Undang terhadap Ketetapan Majelis Permusyawaratan Rakyat sebagai konsekuensi hierarki peraturan perundang-undangan yang diatur dalam 7 ayat (1) huruf b Undang-udang Nomor 12 Tahun 2011 tentang Pembentukan Peraturan Perundang-undangan, tidak memiliki landasan mekanisme atau ketentuan pengujian. Mahkamah Konstitusi tidak serta merta dapat menguji Ketetapan Majelis Permusyawaratan Rakyat, kecuali Ketetapan Majelis Permusyawaratan Rakyat yang berdasarkan ketentuan Pasal 4 Ketetapan Majelis Permusyawaratan Rakyat Nomor I/MPR/2003, yang dipersamakan dengan produk Undang-Undang. 


\section{Daftar Pustaka}

A. Hamid A. Attamimi, Peranan Keputusan Presiden Republik Indonesia dalam Penyelenggaraan Pemerintahan Negara; Suatu Studi Analisis Mengenai Keputusan Presiden yang Berfungsi Pengaturan dalam Kurun Waktu Pelita I-Pelita IV, Disertasi Ilmu Hukum Fakultas Pascasarjana Universitas Indonesia, Jakarta,1990.

Bagir Manan, Dasar-Dasar Perundang-undangan Indonesia, Ind. Hill.Co., Jakarta, 1992.

Jimly Asshidiqie, Sengketa Kewenangan Konstitusional Lembaga Negara, , Konstitusi Pers (cetakan ke-3), Jakarta, 2006

Maria Farida Indrati, IImu Perundang-Undangan Jenis, Fungsi dan Materi Muatan,Kanisius, Yogyakarta,2007.

Moh. Mahfud MD.,Perdebatan Hukum Tata Negara Pasca Amandemen Konstitusi, Rajawali Pers., Jakarta, 2010.

Satjipto Rahardjo, IImu Hukum, PT. Citra Aditya Bakti, Cetakan ke VII., Bandung 2012. 